\title{
Ring Road Development Problems in Metropolitan Cities of Indonesia
}

\author{
Agus Dharma Tohjiwa ${ }^{1^{*}}$, \\ ${ }^{1}$ Department of Architecture, Gunadarma University, Depok, Indonesia.
}

\begin{abstract}
The development of ring roads in Indonesia are not only as a means of transportation needs but also as a means for the urban regional development. Although it produces many economic benefits, this development produces many new problems, especially in metropolitan cities. The aim of this research is to formulate and describe the problems of ring road development in the metropolitan cities of Indonesia. The data collection was carried out through a survey and interview with related institutions in 7 cities, they are Medan, Palembang, Bandar Lampung, Surabaya, Makassar, Manado, and Jakarta. The result of this research shows that there are 23 problems found there. The most common problem found are the uncontrolled housing development (urban sprawl) and public transportation (occurs in 6 cities). The second most problems found are regional connectivity, ring road intersection, housing access, settlement facilities, and social problems (occurs in 5 cities). All the existing problems can be classified into 6 problem types, they are (1) problem of ring road preparation and construction, (2) problem of disobedience and inconsistency of regulation, (3) problem of spatial planning and urban development, (4) problem of housing growth and facilities provision, (5) problem of coordination among institution and regulatory synchronization, and (6) problem of environmental management related to the integration of ring road and settlement development.
\end{abstract}

\section{Introduction}

The high level of population in urban areas that are caused by both natural growth and urbanization impacts on the demand for infrastructures and settlements. Even though the areas for housing and settlement in urban areas are getting increased rapidly, the fact of it shows that there is still a housing numbers gap (backlog) that is always getting increased. The property sector, especially the development of housing complex, has become a sector that is marketable for the investors and it can be predicted that this sector is still going to be increased in the next future years [1].

Several studies have shown that even though improving the regional economy of ring road development has many conflicts of interest [2][3]. Metropolitan cities constitute a large scaled settlement consisting of one or more big cities in integrated areas. The metropolitan cities constitute the National Activities Center (NAC/PKN) that is connected to the primary

\footnotetext{
* Corresponding author : agus_dh@staff.gunadarma.ac.id
} 
arterial road network [4]. The existence of so many vehicles passing the primary arterial road until the city centres account for the government building ring road as replacement of the old primary arterial road. The development of ring road in urban areas recently has become phenomena taking place in some big cities in Indonesia.

The development of ring road impacts the increasing of some new housing complexes. The new buildings of housing complexes can account for various impacts. The lack of arrangement for the urban spatial of urban areas layout can cause the housing complex areas to experience the increase of road network load in some big cities in Indonesia [5]. Housing complex areas grow sporadically, in accordance with the development of the ring road network and it increases the ring road load so that it can be the cause of traffic jams. The phenomena do not occur only in Jakarta but also in some other metropolitan cities and even it becomes issues of urban areas problems that need drawing attention [6]. The research aims at identifying the typology of the emerging problems as an impact of the ring road development in urban areas, especially in metropolitan cities in Indonesia.

\section{Review of ring roads development in Indonesian urban areas}

Regarding with the effort to realize the distribution services that is balanced among areas, Constitution No. 38/2004 on Roads mandates that development of public road is compulsory to draw attention to the unity of the road network system, that is the functional division of arterial, collector, local, and environment roads, and the system of primary and secondary network road [7]. The urban ring road, referring to the function, belongs to the primary arterial road. The technical requirements for the function of the primary arterial road, according to Government Regulation No. 34/2006 on Roads are as follows [8]:

1. Designed based on the lowest plan speed $60 \mathrm{~km} /$ hour and the width of the road at least 11 meters.

2. Have a bigger capacity than the average traffic volume $(\mathrm{V} / \mathrm{C}<1)$;

3. Long distance traffic may not be disturbed by shuttle traffic, local traffic and local activities;

4. Number of driveways is limited in such a way so the item requirements (1), (2), (3) are fulfilled;

5. Plot crossing with certain settings must meet the provisions on items (1), (2), and (3) fulfilled;

6. Should not be interrupted when entering urban areas.

Based on Minister of Public Works Regulation no. 03/PRT/M/2012 on the Guidelines for Road Function Determination and Road Status, it has been set that the function of the primary arterial road is to connect among National Activities Center (NAC/PKN). Illustration for the network system of the primary road can be seen in Figure 1 [9]. 


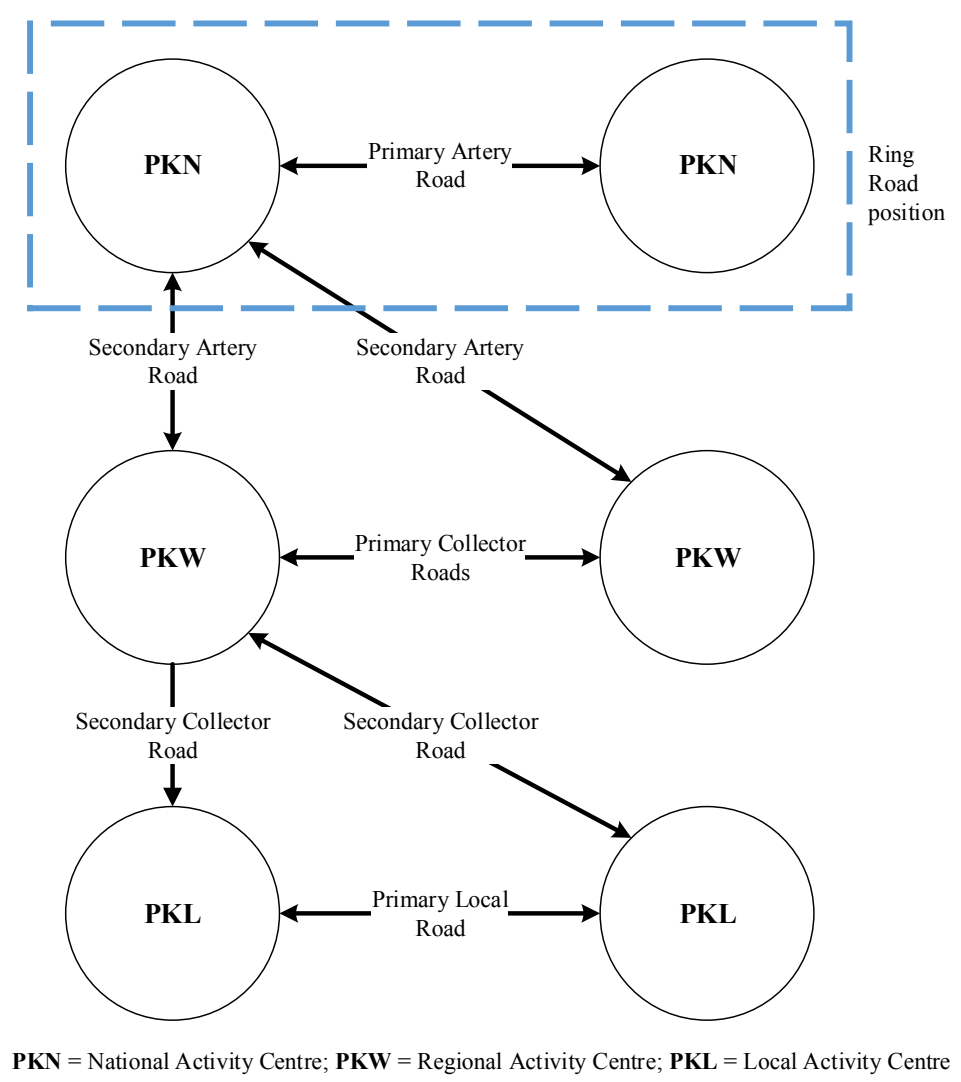

Fig. 1. Primary road network system [9]

At first, the function of the primary arterial road is an interconnection among the National Activities Center (NAC/PKN) that crosses and penetrates the areas of the city center. There is no problem when the city residents are not densely populated, however, the population of city residents is growing rapidly. This condition can account for the function of the existing primary arterial road disturbed and the technical requirements as primary arterial road are not fulfilled. It occurs because the activities of the city residents arouse high mobility and burden the primary arterial road.

The ring road is planned to overcome the problems above. The ring road is a primary arterial road that circles the city center and connects one city to the other cities [10]. The ring road can be in the form of Highways, like in Jakarta or non-highways, such as in the city of Surabaya and Medan. The function of ring road system is to reduce the existing traffic jam in city centre or to reduce the possibilities of the emergence of traffic congestion caused by the entrance of so many vehicles coming from other long-distance regions. If the primary arterial road is understood from its function as the connection among NAC (PKN), the solution for the network system of ring road like this will be more efficient.

The other advantage from the development ring road in the urban hinterland is the development of housing complex and activities of the economy in its surrounding. Besides that, the existence of highway development in the hinterland, the value and the price of land in its surrounding and along with the highways will be getting increased. In general, it can be said that the development of ring road in urban areas can reduce the traffic jam and can also be a means for the developing areas especially in areas of hinterland [11]. 

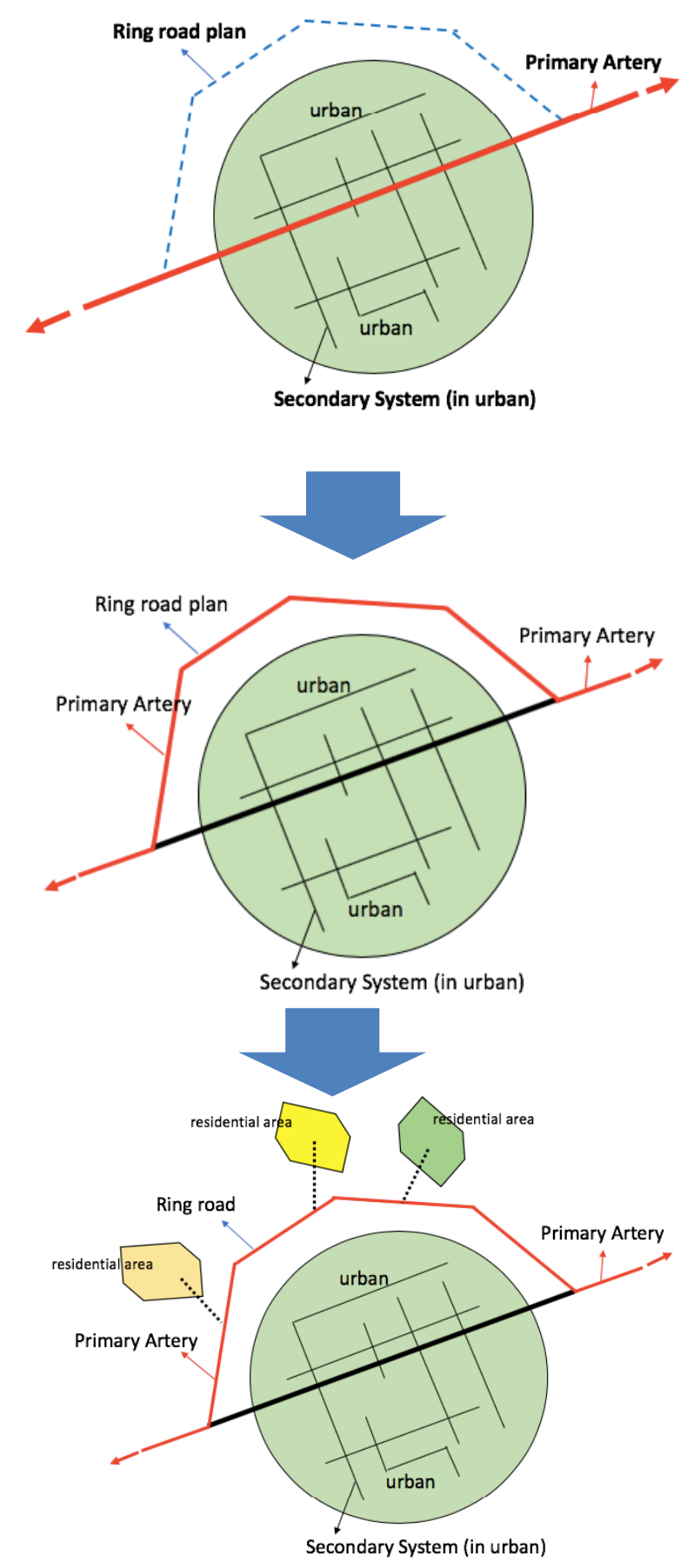

Fig. 2. Regional development as an impact of ring road in urban areas [11]

\section{Stage 1.}

The primary arterial road crosses urban areas before the existence of Ring Road.

\section{Stage 2.}

Ring Road is built to replace the function of primary arterial road crossing urban areas.

The function of old road changes to be a Secondary Arterial road.

\section{Stage 3.}

The impact from the development of ring road in urban areas is the pattern of spreading for the development tends to be closer to the location of ring road location.

Urban regional development is dispersed to the hinterland. 
The development of ring road in urban areas causes the spread pattern of the building for housing complex towards the location of the ring road that is in the hinterland. There are also some new housing complexes that emerge there. The developers are enthusiastic to find the lands that can be built as the housing complex. This condition can stimulate the new problem that is the development of the housing complex that is random and uncontrolled (urban sprawl). Besides the problem above, the general facilities and infrastructures are efficient and adequate because the development of the housing complex is carried out sporadically and without being planned properly [12].

\section{Ring road development problem identification}

The problem identification of ring road development is based on research on ring roads and its surrounding areas conditions. This research is carried out in 7 metropolitan cities, they are Medan, Palembang, Bandar Lampung, Surabaya, Makassar, Manado, and Jakarta. There are four methods applied to collect the data, they are (1) spatial planning review, (2) visual observation, (3) questioner survey for residents living around the ring road, and (4) interview with related agencies/institutions.

Based on the result of the survey carried out in 7 cities above, it can be identified that there are 23 problems in ring road development, they are:

1. Urban/regional connectivity problems. Example: the new ring road in Manado not yet connected with some regions.

2. The width of the ring road problems. Example: road narrowing because of the meeting of new road and old road in Medan inner ring road.

3. Physical condition problems. Example: there are some parts of the inner ring road in Medan that are bumpy and damaged.

4. Traffic jam or congestion problems. Example: traffic jam at rush hour in Jakarta Ring Outer Road (JORR).

5. Intersection the ring road with another road problems. Example: the intersection of the ring road and Collector road in Manado has not been arranged well.

6. The entrance of the house yard connected directly with ring road problems. Example: the front yard of the house directly bordering with the inner ring road in Medan.

7. The roadside barrier that disturbs the traffic of ring road problems. Example: the use of roadside as parking area in ring road in Bandar Lampung.

8. Lack of public transportation facilities and modes problems. Example: there is no bus stop for housing near ring road in Manado.

9. Inappropriate land use change problems. Example: the land around Palembang's ring road changes from farm area to a residential area.

10. Uncontrolled housing growth and urban sprawl problems. Example: many sporadic new housings around Manado' ring road.

11. Dense population problems. Example: density of the population in housing area around Medan's inner ring road.

12. Land legality and incarceration problems. Example: there are many cases of land incarcerations that have been freed for ring road in Makassar.

13. Lack of housing/settlement facilities problems. Example: there are many housing complexes that are not completed with public facilities around ring road in Bandar Lampung.

14. Lack of environmental infrastructure and urban utility problems. Example: there is no drainage and public street lighting in the ring road of Palembang.

15. Housing access from ring road problems. Example: direct access to housing complex from ring road (primary artery) in Manado. 
16. Slum housing problems. Example: many slum housings was built in the roadside area of Bandar Lampung's ring road.

17. Environmental damage problems. Example: the development of a new ring road that potentially damages the environment in Manado.

18. Land acquisition problems. Example: the difficulty to free the land used to middle ring road (MRR) in Makassar because there have been many housing complexes.

19. Synchronization of urban spatial planning problems. Example: Land use rules in Manado's ring road that cross administrative regency boundary is not similar.

20. Coordination among sectors in the local government problems. Example: lack of coordination between street organizer with the local government of Makassar caused many buildings located around the ring road land get permission from the local government.

21. Development financing problems. Example: the land acquisition is carried out periodically in Makassar, due to the lack of financial support. It can lengthen the time to build the ring road.

22. Disaster problems (flood or landslide). Example: construction of Manado's ring road in some locations prone to landslide and flood disaster.

23. Social problems. Example: several locations in Medan ring road are prone to crime at night because of there no street lighting.

Documentation of some problem taking place in ring road and its surrounding areas can be seen in Figure 3.

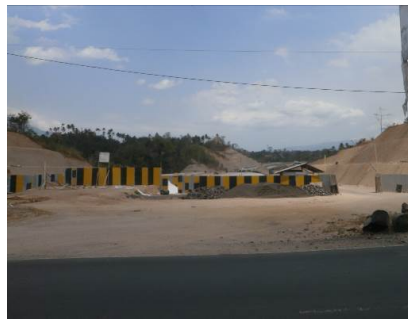

(a) Urban/regional areas connectivity problem

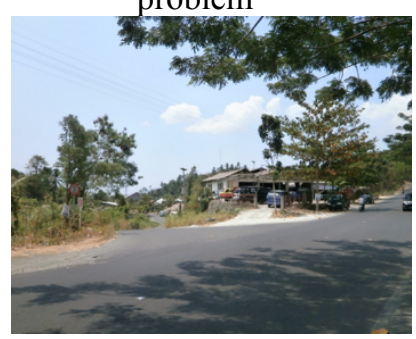

(d) Ring road intersection with another road

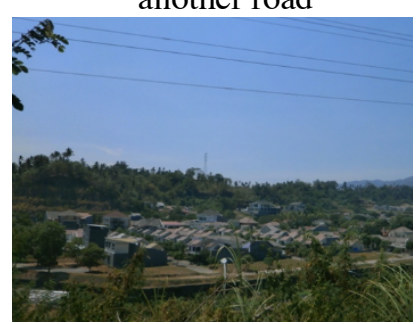

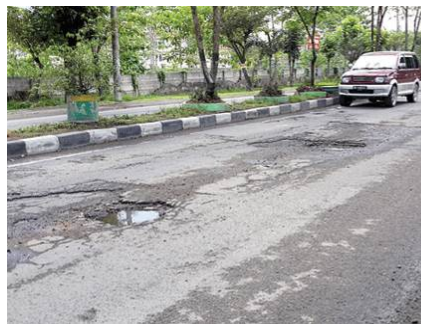

(b) Physical condition problems

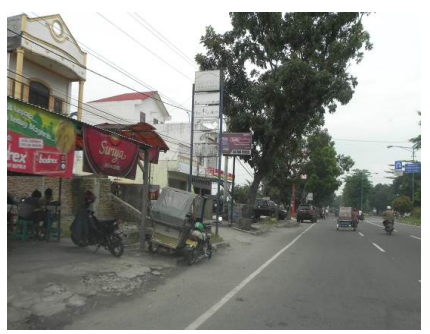

(e) Housing access connected directly with ring road

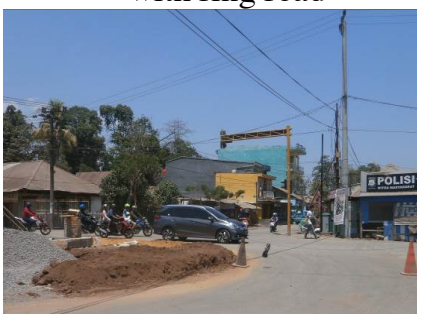

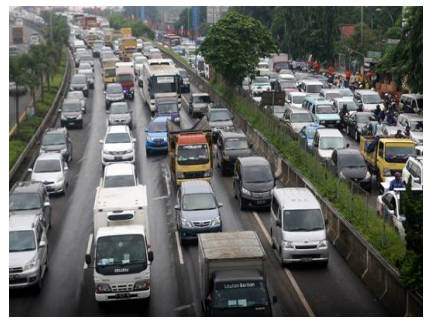

(c) Traffic jam /congestion

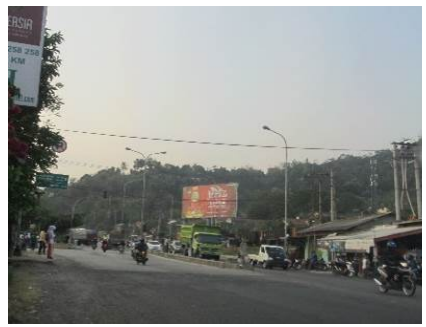

(f) Roadside barrier that disturbs the traffic

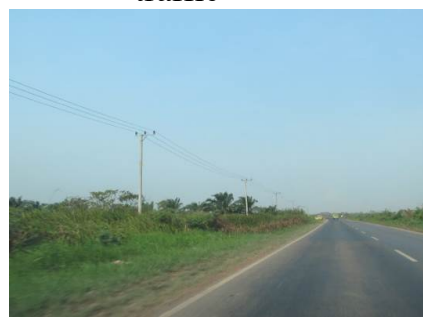



(g) Uncontrolled housing growth and urban sprawl
(h) Land acquisition problems
(i) Lack of environmental and urban utilities

Fig. 3. Documentation of some ring road development problem

Table 1. The location of ring road development problems

\begin{tabular}{|c|c|c|c|c|c|c|c|c|c|}
\hline \multirow[b]{2}{*}{ Number } & \multirow[b]{2}{*}{ Problems } & \multicolumn{7}{|c|}{ Survey location } & \multirow[b]{2}{*}{ 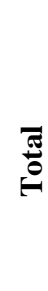 } \\
\hline & & 宽 & 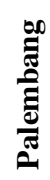 & ف & 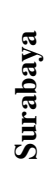 & 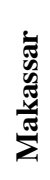 & 畩 & 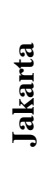 & \\
\hline 1 & Urban and regional connectivity & - & $\sqrt{ }$ & - & $\sqrt{ }$ & $\sqrt{ }$ & $\sqrt{ }$ & $\sqrt{ }$ & 5 \\
\hline 2 & Width of the ring road & $\sqrt{ }$ & - & - & - & - & $\sqrt{ }$ & - & 2 \\
\hline 3 & Physical condition of ring road & $\sqrt{ }$ & - & $\sqrt{ }$ & - & - & - & - & 2 \\
\hline 4 & Traffic jam and traffic congestion & $\sqrt{ }$ & - & $\sqrt{ }$ & $\sqrt{ }$ & - & - & $\sqrt{ }$ & 4 \\
\hline 5 & Intersection the ring road with another road & $\sqrt{ }$ & $\sqrt{ }$ & $\sqrt{ }$ & $\sqrt{ }$ & - & $\sqrt{ }$ & - & 5 \\
\hline 6 & $\begin{array}{l}\text { Entrance of house yard connected directly with } \\
\text { ring road }\end{array}$ & $\sqrt{ }$ & $\sqrt{ }$ & $\sqrt{ }$ & $\sqrt{ }$ & - & $\sqrt{ }$ & - & 5 \\
\hline 7 & Road side obstacle that interfere with traffic & & $\sqrt{ }$ & $\sqrt{ }$ & $\sqrt{ }$ & - & - & - & 3 \\
\hline 8 & Public transportation facilities and modes & $\sqrt{ }$ & $\sqrt{ }$ & $\sqrt{ }$ & $\sqrt{ }$ & - & $\sqrt{ }$ & $\sqrt{ }$ & 6 \\
\hline 9 & Land use change & $\sqrt{ }$ & $\sqrt{ }$ & $\sqrt{ }$ & $\sqrt{ }$ & - & - & - & 4 \\
\hline 10 & Uncontrolled housing growth (urban sprawl) & $\sqrt{ }$ & $\sqrt{ }$ & $\sqrt{ }$ & $\sqrt{ }$ & - & $\sqrt{ }$ & $\sqrt{ }$ & 6 \\
\hline 11 & Population density & $\sqrt{ }$ & - & $\sqrt{ }$ & - & $\sqrt{ }$ & - & $\sqrt{ }$ & 4 \\
\hline 12 & Land legality and land grabs & - & - & - & - & $\sqrt{ }$ & - & - & 1 \\
\hline 13 & Housing/settlement facilities & - & $\sqrt{ }$ & $\sqrt{ }$ & $\sqrt{ }$ & - & $\sqrt{ }$ & $\sqrt{ }$ & 5 \\
\hline 14 & Urban environmental \& utility infrastructure & - & - & $\sqrt{ }$ & - & - & $\sqrt{ }$ & $\sqrt{ }$ & 3 \\
\hline 15 & Accessibility to housing & $\sqrt{ }$ & - & - & $\sqrt{ }$ & & $\sqrt{ }$ & $\sqrt{ }$ & 4 \\
\hline 16 & Slum housing (unfit for habitation) & $\sqrt{ }$ & - & $\sqrt{ }$ & - & - & - & - & 2 \\
\hline 17 & Environmental damage problem & $\sqrt{ }$ & - & $\sqrt{ }$ & - & - & $\sqrt{ }$ & - & 3 \\
\hline 18 & Land acquisition for Ring Road & - & - & - & - & $\sqrt{ }$ & - & - & 1 \\
\hline 19 & Synchronization of Urban Spatial planning & - & - & $\sqrt{ }$ & $\sqrt{ }$ & $\sqrt{ }$ & $\sqrt{ }$ & - & 4 \\
\hline 20 & Sectoral coordination & $\sqrt{ }$ & - & $\sqrt{ }$ & & $\sqrt{ }$ & - & $\sqrt{ }$ & 3 \\
\hline 21 & Ring road development financing & - & $\sqrt{ }$ & $\sqrt{ }$ & - & $\sqrt{ }$ & - & - & 3 \\
\hline 22 & Disaster (flood / landslide) & $\sqrt{ }$ & - & - & - & - & $\sqrt{ }$ & - & 2 \\
\hline 23 & Social problems & $\sqrt{ }$ & $\sqrt{ }$ & $\sqrt{ }$ & $\sqrt{ }$ & $\sqrt{ }$ & - & - & 5 \\
\hline & TOTAL: & 15 & 10 & 17 & 13 & 8 & 12 & 9 & \\
\hline
\end{tabular}

Resume for the location of 23 types of problems above can be seen in Table 1. From the resume, it can be identified that Bandar Lampung has the most problems (17 problems), and followed by Medan (15 problems), and after that Surabaya (13 problems). Makassar has the least problem with all other cities (8 problems). The outer ring road on Makassar at the time of survey has not started the construction phase. 
Based on the data tabulation after being surveyed, it can be identified that the intensity of the problem that is mostly found is uncontrolled housing growth (urban sprawl) and lack of public transportation facilities and modes (occurring in 6 cities). The second most problems found are urban/regional connectivity, intersection the ring road with another road, the entrance of house yard connected directly with ring road, lack of housing/settlement facilities, and social problem (occurring in 5 cities).

\section{Ring road development problems typologies}

From the result of the survey to 7 cities above, it has been identified that there are 23 problems emerging in ring road and its surrounding. The existing problems for each area vary greatly. To gain the general typology of problems, the problems can be classified into the same type of problem [13]. The problems that arise are grouped based on aspects of urban development, spatial planning, housing, regulations, stake holders and environment. Based on these groupings, the typology of ring road development problems for metropolitan cities in Indonesia can be classified into 6 types of problems.

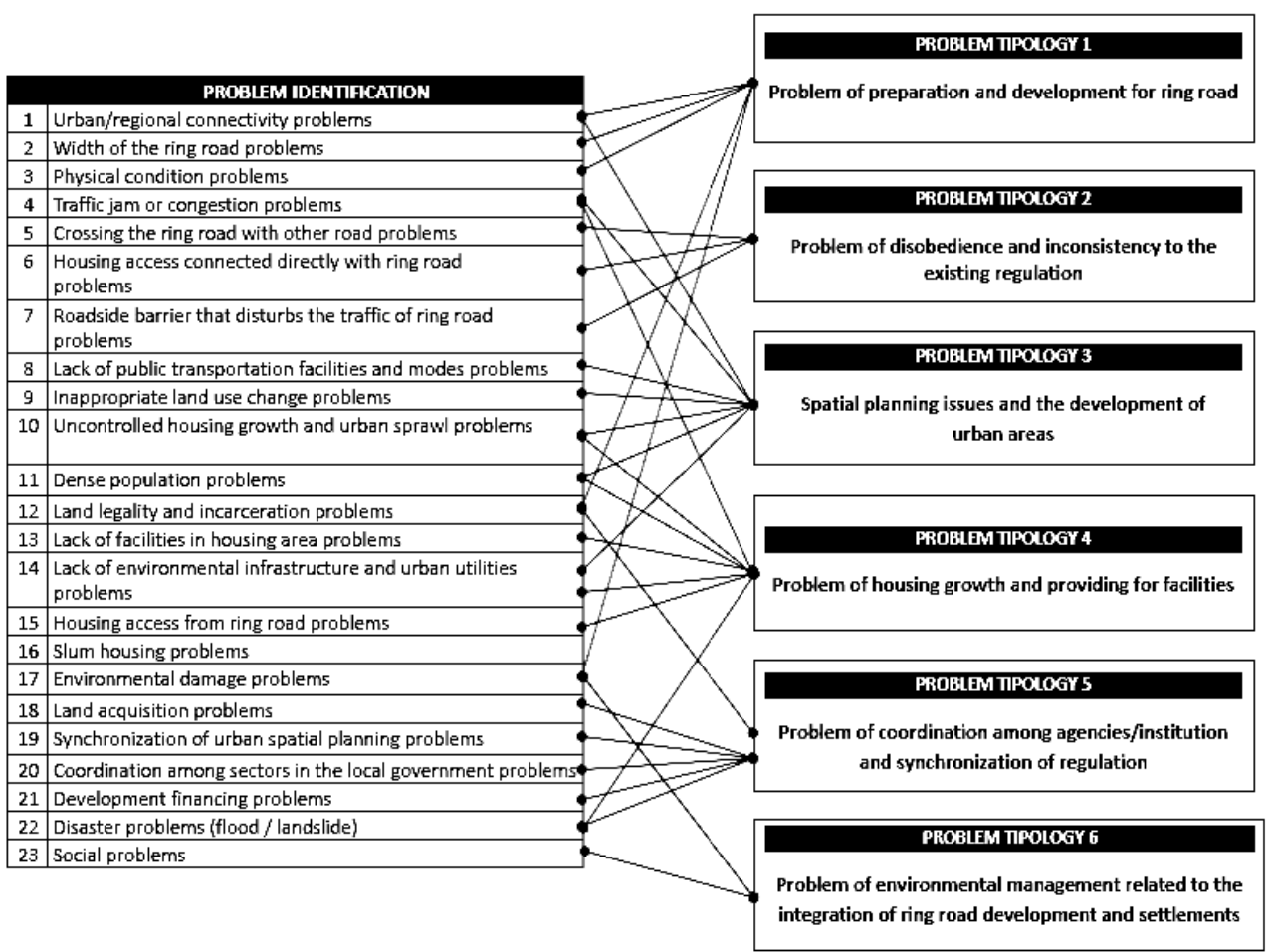

Fig. 4. Problem typologies formulation of ring road development

The 6 problem types of ring road development in Indonesian metropolitan cities can be elaborated as follows:

1. The problem of ring road preparation and construction.

The problem of preparation and development for ring road that is mostly found is the land acquisition problem. Because of the limited financial support from the government, the process of land acquisition cannot be carried out at once. As a result, the process of it takes place together with the settlement growth. Therefore, there are unfinished ring road development or connection in some places. The other problem is if a part of the new ring 
road will be built in dense urban areas. In this case, it is difficult to change the standard of existing roads to be the same as the new ring road.

2. The problem of disobedience and inconsistency of regulation.

There many ring road problems because of disobedience to the existing regulation. As the primary arterial road, ideally the ring road is built as a toll road but in most part of local areas, the ring road is not a toll road. This non-toll ring road has many problems since this road is connected directly to housing complex or settlements. Besides, the fast growth of housing complex/settlements will increase roadside barriers and violations of road borderline.

3. The problem of Spatial planning and urban development.

The development of ring road is usually followed by the development of housing or settlement area in suburbs. The development of spontaneously housing areas sometimes does not fit with local development and spatial planning. There are many new housing area locations that are far from The Regional Activity Center (RAC/PKW). This can impact the increasing of transportation rate and finally will burdening the ring road.

4. The problem of housing growth and facilities provided.

After the information about the new ring road location plan is widespread, the developers usually enthusiastically afford to gain the land near that ring road. This condition can impact uncontrolled housing and urban sprawl. The growth of this such spreading and unplanned housing complex causes the inefficiency of city infrastructures. Besides, it is found that some developers do not provide public facilities that have been instructed by settlement regulation. It is also found that several housing complexes near ring road do not have road access yet or the road access is not proper.

5. The problem of coordination among institution and regulatory synchronization.

The lack of coordination among agencies/institutions can cause problems related to building permits. In several places, it is still found some problems concerning the building permit on the ring road location. The issue of building permission (IMB) complicates the land acquisition for ring road development. In some places found that location of the ring road is across administrative boundaries. This condition needs coordination among local governments. They should be synchronizing the development regulation especially in arranging harmonious spatial regulation in areas that passed by the ring road.

6. The problem of environmental management related to the integration of ring road and

settlement development

The development of ring road and settlements in its surrounding has the potential to damage the environment. This case should be anticipated from the beginning of ring road planning. The growth of housing areas must also be planned well to obtain the health and the comforting environment. In some cases, it is also found some slum settlements located around ring road that disturb environmental aesthetics. The growth of the slum settlements must be immediately controlled, and its environment must also be re-arranged.

\section{Conclusion}

Infrastructure plays an important and vital role in supporting national development especially in facilitating interaction and communication among the community as well as binding and linking between regions. Through this research we know that there are 23 problems that have arisen in ring road development in Indonesian metropolitan cities. These 23 problems can be grouped into 6 main problem typologies.

We can conclude that development of the ring road can be seen in two aspects, namely as a means of connectivity between cities and as a means of regional development. As a means of connectivity between National Activities Center (NAC/PKN), Ring Road must apply the regulation or standard of Primary Arterial Road while as a means of development of housing growth area around ring road must be in line with Spatial Planning and regulation or standard 
of settlement planning. The lack of integration of these two aspects will cause problems and constraints of urban development which has a devastating effect on regional development.

There should be an institution to coordinate all parties involved in the ring roads development process from the beginning. In the case of metropolitan cities in Indonesia, Bappeda (Regional Planning Agency) at the provincial level can take on this task. Besides that, strict law enforcement is also the key to the success of development

\section{References}

1. Direktorat Jendral Penataan Ruang Departemen Pekerjaan Umum. Metropolitan di Indonesia: Kenyataan dan Tantangan dalam Penataan Ruang (2002).

2. Rahman, Frasandy Sartika, et al. International Journal of Engineering and Science, 8-1, pp. 21-25 (2018).

3. Bahana, Wilda Wija and Rini Rachmawati. Jurnal Bumi Indonesia, 4-4 (2015).

4. Law No. 26/2007 concerning Spatial Planning

5. Sumaryoto, S. Jurnal R\&D, 12-1. pp.10-17 (2011).

6. Wunas, S. Kota Humanis: Integrasi Guna Lahan dan Transportasi di Wilayah Suburban. Surabaya. Brilian Internasional (2011).

7. Undang-undang No. 38/2004 tentang Jalan.

8. Peraturan Pemerintah No. 34/2006 tentang Jalan.

9. Peraturan Menteri Pekerjaan Umum No. 03/PRT/M/2012 tentang Pedoman Penetapan Fungsi Jalan dan Status Jalan.

10. L. Stephen, et al. IRJET. 03-09. pp.1362-1365 (2016).

11. Sutono, Sistem Jaringan Jalan Penetapan Fungsi dan Status Jalan, Ditjen Bina Marga Kementerian PU (2012).

12. N. G. Koppel, N. Ginsburg, T.G. McGee (eds). The Extended Metropolis: Settlement Transition in Asia. Honolulu. University of Hawaii Press (1991).

13. J. W. Cresswell. Research Design: Qualitative, Quantitative, and Mix Methods Approaches. California. Sage Publications (2002). 